\title{
Intake and milk production of suckling ewes reared at pasture in humid tropics according to the post-grazing residue management
}

\author{
Eusebio ORTEGA-JIMENEZ ${ }^{\mathrm{a}}$, Gisèle ALEXANDRE ${ }^{\mathrm{b} *}$, Maryline BOVAL $^{\mathrm{b}}$, \\ Harry ARCHIMÈDE ${ }^{\mathrm{b}}$, Maurice MAHIEU ${ }^{\mathrm{b}}$, Alain XANDÉ ${ }^{\mathrm{b}}$
}

\footnotetext{
a Campus Veracruz-Colegio de Postgraduados, Apdo. Postal: 421 Veracruz, Veracruz, Mexico b INRA, Unité de Recherches Zootechniques, Centre Antilles-Guyane, Domaine Duclos, 97170 Petit Bourg, Guadeloupe
}

(Received 3 December 2004; accepted 9 August 2005)

\begin{abstract}
Experiments were designed with Martinik suckling ewes, reared on rotationally grazed tropical pasture, in order to test the effect of post-grazing residue control on forage intake and milk production. A system in which residuals were mown (RM) was compared to the control (Residuals Remained, RR) during three seasons (dry, intermediate and wet). Each group at each season was composed of 20 ewes $(46.8 \pm 2.4 \mathrm{~kg} \mathrm{LW})$. Milk production (oxytocin method), live weight (LW), body condition score (BCS) and intake (fecal index method) were determined on six multiparous twin-bearing ewes in each group and at each season $(47.5 \pm 6.0 \mathrm{~kg} \mathrm{LW})$. The herbage biomass and chemical composition were at a satisfactory level for tropical forages: biomass on offer reached 2.54 vs. $3.75 \mathrm{t}^{-h^{-1}} \mathrm{DM},(P<0.001)$ for RM and RR, respectively; and the $\mathrm{CP}$ content was around $100 \mathrm{~g} \cdot \mathrm{kg}^{-1}$. The DMI and OMI, expressed as $\mathrm{g} \cdot \mathrm{kg}^{-0.75}$, were $103 \pm 18$ and $81 \pm 14$, respectively. On average, the daily milk production of the ewes reached $1.2 \pm 0.3 \mathrm{~kg} \cdot \mathrm{d}^{-1}$. The fat and protein contents of the milk were $66 \pm 17$ and $52 \pm 13 \mathrm{~g} \cdot \mathrm{kg}^{-1}$, respectively. The ewes did not significantly loose LW or BCS during lactation. No significant differences in MP and intake traits were observed in terms of pasture management and seasonal effects. The forage characteristics were not limiting factors and generated an adequate level of intake and production whatever the pasture management system.
\end{abstract}

intake / milk production / Martinik ewe / tropical pasture

Résumé - Ingestion et production laitière de brebis allaitantes élevées au pâturage en zone tropicale humide en fonction du mode de gestion des refus au pâturage. Les effets de la fauche des refus au pâturage sur l'ingestion du fourrage et sur la production laitière ont été étudiés chez des brebis Martinik allaitantes élevées dans un pâturage tournant. Un système dans lequel les refus étaient fauchés à la fin du cycle de pâturage (RM) a été comparé au témoin (RR) au cours de 3 saisons (sèche, intermédiaire et humide). Chaque groupe (RM vs. RR) était composé à chaque saison de 20 brebis $(46,8 \pm 2,4 \mathrm{~kg})$. La production laitière (PL, méthode à l'ocytocine), le poids vif, l'état corporel et l'ingestion (méthode des index fécaux) ont été déterminés sur 6 multipares élevant des agneaux

* Corresponding author: alexandre@ antilles.inra.fr 
doubles $(47,5 \pm 6,0 \mathrm{~kg})$ dans chaque système et à chaque saison. La productivité et la composition chimique du fourrage étaient à des niveaux satisfaisants pour des fourrages tropicaux : la biomasse atteignait 2,54 vs. $3,75 \mathrm{t} \cdot \mathrm{ha}^{-1} \mathrm{MS},(P<0,001)$ pour RM et RR, respectivement, et le taux de matières azotées totales était d'environ $100 \mathrm{~g} \cdot \mathrm{kg}^{-1}$. La matière sèche et la matière organique ingérées étaient de $103 \pm 18$ et $81 \pm 14$ en $\mathrm{g} \cdot \mathrm{kg}^{-0,75}$, respectivement. La PL a atteint en moyenne $1,2 \pm 0,3 \mathrm{~kg} \cdot \mathrm{j}^{-1}$ sur 11 semaines de lactation. Les matières grasse et azotée du lait étaient de $66 \pm 17$ et $52 \pm 13 \mathrm{~g} \cdot \mathrm{kg}^{-1}$, respectivement. Les femelles n'ont pas perdu significativement de poids ni de note d'état corporel au cours de la lactation. Aucune différence significative entre les 2 traitements et les différentes saisons n'a été observée pour l'ingestion et pour la production du lait.

ingestion / production laitière / brebis Martinik / pâturage tropical

\section{INTRODUCTION}

In the West Indies, suckling ewes and their offspring are mainly raised under extensive systems of production. The most widespread feeding mode is grazing $[11,21]$ and this is mainly based on natural, unimproved savannahs, which lead to poor animal performance.

In the past 20 years, animal output improvement has been obtained owing to an accelerated rate of reproduction and intensive management with the local breed, the Martinik hair sheep [21]. The ewes weighing about $45 \mathrm{~kg}$ live-weight (LW) present high reproductive capacities and produce up to $28 \mathrm{~kg} \mathrm{LW}$ of weaned offspring per dam per year (i.e. $2 / 3$ of the LW ewe). The main feeding system is based on rotationally-grazed pastures, exploited at 28 to 35 days. However, tropical forage even when fertilised and irrigated is of moderate food value $[4,22]$, which is a major limiting factor in animal production. Providing supplements allows very high animal performances as shown in a previous study with the same genotype [2] but such a practice is expensive and not well adapted to tropical conditions. It is therefore necessary to optimise the use of forages at pasture and develop management approaches for harvesting high-quality forages.

In tropical conditions, even intensive grazing systems generate high post-grazing residues as those tested in the past in the Martinique with sheep [21]. The same problems have been underlined in grazing experiments carried out with dairy cows in New Zealand [16] or with meat cattle in
Brazil [10]. This seems to be a major problem with tropical forages that are productive but presenting high contents of cell walls $[17,22]$. Exploiting the forage with less than one month of regrowth may lead to a better digestibility and ingestibility [3, 4] and it has been successfully used for housed animals but not at pasture because of the impact of high levels of gastrointestinal-parasitism associated with the practice [5].

Experiments aimed at the control of such residues were designed and carried out over a two-year experiment. The objective of this paper was to investigate the effect of post-grazing residue management on forage intake and milk production of suckling ewes assuming that the modifications of forage availability and sward structure can improve the intake level of grazing ruminants [7, 22, 24]. These traits were assessed over the first year of the trial. The results on the reproductive cycle, growth rate of the offspring and flock productivity over a twoyear experiment have been analysed in another paper [23].

\section{MATERIALS AND METHODS}

This study was carried out in Guadeloupe, which is a humid tropical island within the Caribbean $\left(16.1^{\circ} \mathrm{N}, 61.6^{\circ} \mathrm{W}\right)$. The experimental farm is located in the driest area where annual rainfall averages $1280 \mathrm{~mm}$, with a dry season lasting from January to May with less than $70 \mathrm{~mm}$ per month. Maximum air temperature varies from $27^{\circ} \mathrm{C}$ (January) to $32^{\circ} \mathrm{C}$ (August) with 
Table I. Botanical composition of the sward grazed by Martinik sheep under different postgrazing residue managements (residuals mown $\mathrm{RM}$ vs. residuals remained $\mathrm{RR}$ ) at the beginning of the experiment.

\begin{tabular}{lcc}
\hline Pasture management & RM & RR \\
\hline Stoloniferous creeping species & & \\
Digitaria decumbens & $29 \%$ & $36 \%$ \\
Dichanthium sp. & $36 \%$ & $40 \%$ \\
Brachiaria mutica & $4 \%$ & $7 \%$ \\
Cynodon dactylon & $4 \%$ & $4 \%$ \\
Tall bunch grass & & \\
$\begin{array}{l}\text { Panicum maximum } \\
\text { Miscellaneous }\end{array}$ & $20 \%$ & $5 \%$ \\
Forbs and other grasses & $7 \%$ & $8 \%$ \\
\hline
\end{tabular}

the minimum from $21^{\circ} \mathrm{C}$ to $25^{\circ} \mathrm{C}$, respectively. Relative humidity is usually above $70 \%$ and the day length range from $11 \mathrm{~h}$ to $13 \mathrm{~h}$.

\subsection{Experimental design}

Two plots of a pasture based on tropical grasses were compared on the basis of sward management. Two methods of rotationally-grazed pasture were tested. In the first treatment, when the animals were moved out of the paddock, the sward was mowed and the post-grazing residues were removed. This system was called "residuals mowed" (RM). It was compared to the control system where residuals were not mowed and remained on the paddock (RR). At each season, each plot was grazed by 20 females (half of them were lactating and half were pregnant). The two pasture management methods were compared at three lambing seasons per year. The experiment lasted for one year.

\subsection{Pasture management}

The sward botanical composition of the different paddocks was determined [12] and the results are shown in Table I. Prior to the experiment, the pastures were mown to $3-5 \mathrm{~cm}$ above ground. Each plot was grazed under its respective management during a two month-period of adaptation. Year round grazing was done and pastures were rotated at 28 days age of regrowth. For both pasture management, each plot of $6250 \mathrm{~m}^{2}$ was equally divided into 5 paddocks (the animals grazed the forage within each paddock for 7 days). The pastures were irrigated and fertilised with $150 \mathrm{~kg} \cdot \mathrm{ha}^{-1} \cdot \mathrm{y}^{-1}$ nitrogen. When the animals were moved out of the paddock, each paddock received an application of a 30-12-18 N-P-K fertiliser. In the RM system, all the post-grazing residues were mowed with a lawnmower fitted with a grass collector.

\subsection{Animals and their management}

Martinik ewes were used in the experiment; there were 20 females at each season in each plot. The mean initial live weights (LW) were $47.4 \pm 2.9 \mathrm{~kg}$ and $46.2 \pm 2.4 \mathrm{~kg}$ for the RM and RR groups respectively. The ewe parities were $3.8 \pm 2.1$ and $4.0 \pm$ 2.5 for RM and RR groups, respectively. The animals were subjected to three parturitions within 2 years in the mating system. The lambing periods occurred during the dry season (DS: mid-January to mid-February), the intermediate season (IS: midApril to mid-May) and the wet season (WS: mid-September to mid-October). Weaning took place at an average age of $81.4 \pm$ 3.6 days. Regular drenchings were carried out in order to avoid any nematode infestation (intramuscular moxidectin injection), every two weeks for the young and dams from birth to weaning and every month for adults during the mating and pregnancy periods. External parasites were controlled every two weeks for the young and adults (spray of flumethrin acaricides).

\subsection{Forage sampling procedures}

Biomass and chemical composition of the herbage were determined before grazing. Forage measurements were carried out three times during each season upon one 
representative paddock per system. Herbage mass was estimated by cutting $10 \times$ $0.09 \mathrm{~m}^{2}$ quadrats with hand-held electric clippers. The samples were weighed fresh and a subsample of $300 \mathrm{~g}$ was kept for dry matter and chemical determination.

\subsection{Herbage intake and animal performances}

For each season and in each treatment group, six multiparous twin-suckling ewes $(47.5 \pm 6.0 \mathrm{~kg} \mathrm{LW})$ were used to assess herbage intake and milk production.

The herbage intake was assessed twice in the dry season and three times during the two other seasons. When the flock was let into the representative paddock, the animals grazed the forage within the paddock for 7 days, the females were fitted with faecal bags during the last 5 days of the week which was defined as the measurement period.

Organic matter intake per day was determined from total faecal OM output and OM digestibility. Faecal output per day was measured by collecting all faeces excreted by each female in individual bags, over the 5-day measurement period. Faeces collection was carried out twice daily $(7 \mathrm{~h}$ and $17 \mathrm{~h}$ ) to limit the bag weight constraint for the animals. For each female, the entire amount of collected faeces over the 5-day measurement period was weighed. The faeces were then mixed and homogenised and a sub-sample of $300 \mathrm{~g}$ was taken to determine dry matter (DM), OM, CP and fibre content.

OM digestibility (OMD) was estimated for each female from the CP content of the faecal sub-sample (CPf, $\left.\mathrm{g} \cdot \mathrm{kg}^{-1} \mathrm{OM}\right)$, according to an equation established by Boval et al. [8], with sheep fed on tropical herbage in the West Indies environment:

$$
\mathrm{OMD}=0.8663-2.6623 / \mathrm{CPf} \text {. }
$$

Organic matter intake per day (OMI, $\mathrm{kg} \cdot \mathrm{d}^{-1} \mathrm{OM}$ ) was then calculated according to the following equation: $\mathrm{OMI}=$ faecal OM output /(1 - OM digestibility).
For each season and in each treatment group, the milk production of the same six multiparous twin-suckling ewes was recorded weekly from the first to the 11th week of lactation, using the oxytocin method described by Doney et al. [13]. Oxytocin was administrated at the rate of 5 I.U. by intravenous injection twice at a 4 hour interval followed by hand milking. The first milking was carried out to remove the milk from the udder and at the second milking, 4 hours later, the milk was weighed and the data recorded. Ewes were weighed every week and a body condition score (BCS), assessed by two scorers, was attributed to each female according to the method of Russel et al. [26].

\subsection{Chemical analyses}

Dry matter contents of both herbage and faeces samples were determined by drying until constant weight at $60{ }^{\circ} \mathrm{C}$ in a forceddraught oven. The samples were then ground $(0.5 \mathrm{~mm})$ prior to chemical analysis. The OM content was measured after a $10 \mathrm{~h}$ pyrolysis at $550{ }^{\circ} \mathrm{C}$. Neutral detergent fibre (NDF), acid detergent fibre (ADF) and acid detergent lignin (ADL) were estimated following the methods of Van Soest et al. [28]. Nitrogen concentration was determined by the Dumas method [1]; protein content was calculated by multiplying the nitrogen content by 6.25 . The milk fat and protein contents were determined by infrared spectrophotometry.

\subsection{Data calculations and statistical analyses}

The energy supply and balances were expressed in UFL (Unité Fourragère Lait) according to the French Feed Unit Systems [18]. The energy supply with the grazed grass was estimated per day using a predictive regression from OMD for tropical grass at different stages of regrowth [4]:

$$
\mathrm{UF}=(1.55 \times \mathrm{OMD}) \times \mathrm{OMI}
$$


The protein supply and balances were expressed in the PDI system (Protein truly digestible in the small intestine; [18]) of which one of the two components, PDIN is the sum of two fractions:

PDIN = PDIA + PDIMN; where PDIA is the dietary protein undegraded in the rumen and truly digestible in the small intestine and PDIMN is the microbial true protein truly digestible in the small intestine that could be synthesised from the degraded dietary N. PDIA and PDIMN were estimated using the following equations available for tropical forages of the region [4]:

PDIA $=1.11 \times \mathrm{CP}(1-\mathrm{TD}) \times \mathrm{dr} \times 1$; where $\mathrm{TD}=0.53$ and $\mathrm{dr}=70 \%$.

$\mathrm{PDIMN}=\mathrm{CP} \times 0.2752$.

The other component PDIE is the sum of two fractions:

PDIE = PDIA + PDIME; where PDIME is the microbial true protein truly digestible in the small intestine that could be synthesised from the energy (E). The PDIE value of the forage was calculated according to the INRA system [18].

The herbage data and the LW and BCS of reproducing females were analysed using the SAS general linear model [27]. The model contains effects due to pasture management (PM), lambing season (S) and pasture management $\times$ lambing season interaction. The model was as follows:

$Y_{i j}=m+P M_{i}+S_{j}+(P M \times S)_{i j}+e_{i j}$ (model 1)

where $\mathrm{m}$ is the mean; $\mathrm{PM}_{\mathrm{i}}$ is the pasture management effect $(i=1,2) ; S_{j}$ is the season effect $(\mathrm{j}=1,2,3)$; $(\mathrm{PM} \times \mathrm{S})_{\mathrm{ij}}$ is the pasture management $\times$ lambing season interaction and $\mathrm{e}_{\mathrm{ij}}$ is the residual term.

The ewe's milk production and composition were analysed using the SAS general linear model [27] according to the following model:
$\mathrm{Y}_{\mathrm{ij}}=\mathrm{m}+\mathrm{PM}_{\mathrm{i}}+\mathrm{S}_{\mathrm{j}}+(\mathrm{PM} \times \mathrm{S})_{\mathrm{ij}}+$

$b_{1} L_{i j}+b_{2} B S_{i j}+e_{i j}$ (model 2)

where $\mathrm{m}$ is the mean; $\mathrm{PM}_{\mathrm{i}}$ is the pasture management effect $(i=1,2) ; S_{j}$ is the season effect $(\mathrm{j}=1,2,3)$; $(\mathrm{PM} \times \mathrm{S})_{\mathrm{ij}}$ is the pasture management $\times$ lambing season interaction; $\mathrm{b}_{1} \mathrm{LW}_{\mathrm{ij}}$ is the covariable live weight of the ewe; $b_{2} \mathrm{BCS}_{\mathrm{ij}}$ is the covariable body condition score of the ewe and $\mathrm{e}_{\mathrm{ij}}$ is the residual term.

The daily DMI and OMI were analysed using the SAS general linear model [27] according to the following model:

$\mathrm{Y}_{\mathrm{ijk}}=\mathrm{m}+\mathrm{PM}_{\mathrm{i}}+\mathrm{S}_{\mathrm{j}}+(\mathrm{PM} \times \mathrm{S})_{\mathrm{ij}}+$

$\mathrm{b}_{1}$ biom $_{\mathrm{ijk}}+$ stage $_{\mathrm{k}}+\mathrm{e}_{\mathrm{ijk}} \quad$ (model 3)

where $\mathrm{m}$ is the mean; $\mathrm{PM}_{\mathrm{i}}$ is the pasture management effect $(i=1,2) ; S_{j}$ is the season effect $(j=1,2,3)$; $(P M \times S)_{i j}$ is the pasture management $\times$ lambing season interaction; Stage $_{\mathrm{k}}$ is the stage of lactation $(\mathrm{k}=1,2,3)$; $\mathrm{b}_{1}$ biom $_{\mathrm{ijk}}$ is the covariable biomass on offer the week of milk control and $\mathrm{e}_{\mathrm{ijk}}$ is the residual term.

\section{RESULTS}

\subsection{Herbage characteristics on offer and intake}

The biomass and chemical composition of the herbage on offer when the animals were let into the paddock are presented in Table II. The herbage mass reached 2.54 vs. $3.75 \mathrm{t} \cdot \mathrm{ha}^{-1} \mathrm{DM},(P<0.001)$ in RM and RR plots, respectively. The values for the $\mathrm{CP}$ content ranged from 87 to $114 \mathrm{~g} \cdot \mathrm{kg}^{-1} \mathrm{DM}$ and from 79 to $91 \mathrm{~g} \cdot \mathrm{kg}^{-1} \mathrm{DM}$. The CP content was significantly higher $(16 \%$ more; $P<0.05)$ in the RM pastures than in the RR ones. There was a seasonal effect upon forage mass $(P<0.01)$ and protein content $(P<0.05)$ in favour of the wet season over the two other ones. Whatever the plots, the NDF and ADF forage contents were on average 720 and $360 \mathrm{~g} \cdot \mathrm{kg}^{-1} \mathrm{DM}$, respectively. A significant season effect $(P<0.05)$ was observed upon the ADF values. 
Table II. Herbage characteristics on offer in rotationally-grazed pasture by suckling ewes according to pasture management and season: biomass $\left(\mathrm{t} \cdot \mathrm{ha}^{-1}\right)$ and chemical composition $\left(\mathrm{g} \cdot \mathrm{kg}^{-1} \mathrm{DM}\right)$.

\begin{tabular}{|c|c|c|c|c|c|c|c|c|c|c|}
\hline & \multicolumn{3}{|c|}{ Residuals mown } & \multicolumn{3}{|c|}{ Residuals remained } & \multirow[b]{2}{*}{ SEM } & \multicolumn{3}{|c|}{ Effect of } \\
\hline & DS & IS & WS & DS & IS & WS & & PM & $\mathrm{S}$ & $\mathrm{PM} \times \mathrm{S}$ \\
\hline Biomass & 2.65 & 2.38 & 2.58 & 3.05 & 3.82 & 4.39 & 302 & $P<0.001$ & $P<0.01$ & $P<0.05$ \\
\hline Crude protein & 95 & 87 & 114 & 85 & 79 & 91 & 13 & $P<0.05$ & $P<0.05$ & NS \\
\hline Neutral detergent fibre & 699 & 724 & 748 & 706 & 726 & 740 & 91 & NS & NS & NS \\
\hline Acid detergent fibre & 348 & 335 & 368 & 345 & 349 & 373 & 38 & NS & $P<0.05$ & NS \\
\hline
\end{tabular}

DS: dry season, IS: intermediate season, WS: wet season.

Effect of pasture management $(\mathrm{PM})$, season $(\mathrm{S})$ or interaction $\mathrm{PM} \times \mathrm{S}$ : level of significance; NS: non significant.

Table III. Forage organic matter digestibility (OMD), dry matter (DMI) and organic matter intake (OMI) for suckling ewes reared in rotationally-grazed pasture according to pasture management and season.

\begin{tabular}{|c|c|c|c|c|c|c|c|c|c|c|}
\hline & \multicolumn{3}{|c|}{ Residuals mown } & \multicolumn{3}{|c|}{ Residuals remained } & \multirow[b]{2}{*}{ SEM } & \multicolumn{3}{|c|}{ Effect of } \\
\hline & DS & IS & WS & DS & IS & WS & & PM & $S$ & $\mathrm{PM} \times \mathrm{S}$ \\
\hline OMD & 0.656 & 0.675 & 0.681 & 0.678 & 0.682 & 0.678 & 0.090 & NS & NS & NS \\
\hline $\mathrm{DMI}^{*}\left(\mathrm{~g} \cdot \mathrm{kg}^{-0.75}\right)$ & 112 & 106 & 101 & 100 & 103 & 94 & 18 & NS & NS & $P<0.05$ \\
\hline OMI* $\left(\mathrm{g} \cdot \mathrm{kg}^{-0.75}\right)$ & 89 & 82 & 80 & 79 & 82 & 77 & 14 & NS & NS & $P<0.05$ \\
\hline
\end{tabular}

DS: dry season, IS: intermediate season, WS: wet season.

Effect of pasture management $(\mathrm{PM})$, season $(\mathrm{S})$ or interaction $\mathrm{PM} \times \mathrm{S}$ : level of significance; NS: non significant.

* Value adjusted for stage of lactation and level of herbage biomass on offer.

The values of OMD, DMI and OMI, adjusted for the stage of lactation and level of herbage biomass on offer are presented in Table III. Whatever the pasture management and the season, the OMD, DMI and OMI were on average $0.675,103 \mathrm{~g} \cdot \mathrm{kg}^{-0.75}$ and $81 \mathrm{~g} \cdot \mathrm{kg}^{-0.75}$, respectively. No difference between pasture management systems or between seasons was shown. A significant interaction between treatment and season was observed for the intake values. The levels of DMI and OMI in the dry season were higher for the RM than for the RR ewes $\left(112\right.$ vs. $100 \mathrm{~g} \cdot \mathrm{kg}^{-0.75} ; P<0.05$ and 89 vs. $\left.79 \mathrm{~g} \cdot \mathrm{kg}^{-0.75} ; P<0.05\right)$.

\subsection{Animal performances}

Values of milk production, adjusted for BCS and LW, are presented in Table IV, according to pasture management group and lambing season. The daily milk production over the 11 weeks of lactation averaged $1.20 \mathrm{~kg} \cdot \mathrm{d}^{-1}$ in the two groups. No significant difference was observed in terms of pasture management while a significant $(P<0.05)$ interaction between pasture management and season was noted. During the dry season, the MP of the RM ewes were higher $(P<0.05)$ than those of the RR ewes $(20 \%$ of difference).

The chemical composition of the milk is presented in Table IV. The fat and protein contents reached on average 66 and $52 \mathrm{~g} \cdot \mathrm{kg}^{-1}$, respectively. For both traits, there was no pasture management or season effect. The milk fat content was significantly higher $(P<0.05)$ for RM than for the RR ewes only during the intermediate season 71 vs. $60 \mathrm{~g} \cdot \mathrm{kg}^{-1}$. 
Table IV. Milk production (MP) and composition of multiparous twin-bearing ewes reared in rotationally-grazed pasture according to pasture management and season.

\begin{tabular}{|c|c|c|c|c|c|c|c|c|c|c|}
\hline & \multicolumn{3}{|c|}{ Residuals mown } & \multicolumn{3}{|c|}{ Residuals remained } & \multirow[b]{2}{*}{ SEM } & \multicolumn{3}{|c|}{ Effect of } \\
\hline & DS & IS & WS & DS & IS & WS & & PM & $S$ & $\mathrm{PM} \times \mathrm{S}$ \\
\hline $\mathrm{MP}^{*}\left(\mathrm{~kg} \cdot \mathrm{d}^{-1}\right)$ & 1.20 & 1.24 & 1.28 & 1.00 & 1.39 & 1.18 & 0.31 & NS & NS & $P<0.05$ \\
\hline Fat content $\left(\mathrm{g} \cdot \mathrm{kg}^{-1}\right)$ & 67 & 71 & 68 & 67 & 60 & 66 & 16 & NS & NS & $P<0.05$ \\
\hline $\mathrm{CP}$ content $\left(\mathrm{g} \cdot \mathrm{kg}^{-1}\right)$ & 51 & 54 & 55 & 53 & 50 & 52 & 13 & NS & NS & NS \\
\hline
\end{tabular}

DS: dry season, IS: intermediate season, WS: wet season.

Effect of pasture management $(\mathrm{PM})$, season $(\mathrm{S})$ or interaction $\mathrm{PM} \times \mathrm{S}$ : level of significance; NS: non significant.

* Value adjusted for LW and BCS of the ewe.

The variation in weight of the females (Fig. 1) was $-2.2 \mathrm{~kg}$ and $-1.4 \mathrm{~kg} \mathrm{LW}$, between the beginning and end of the lactation period for RM and RR ewes, respectively (i.e. 3.9 and $2.5 \%$ relative loss, respectively). The mean BCS averaged 2.5 at the beginning of lactation and 2.4 at the end (Fig. 1). These traits were not affected by pasture management or season.

\subsection{Energy and protein supplies and balances}

The energy supply and total energy requirements were estimated to be $1.56 \mathrm{vs}$. $1.46 \mathrm{UFL} \cdot \mathrm{d}^{-1}$ and $1.41 \mathrm{vs} .1 .31 \mathrm{UFL} \cdot \mathrm{d}^{-1}$, respectively for the RM Vs. RR ewes (Tab. V). Whatever the group of ewes and the season, the energy balance was positive and averaged $0.14 \mathrm{UFL} \cdot \mathrm{d}^{-1}$. The PM, season and $\mathrm{PM} \times \mathrm{S}$ effects were significant. The values were higher for RM than for RR ewes $(15 \%$ more, $P<0.05)$ and during the dry season $\left(0.23 \mathrm{UFL} \cdot \mathrm{d}^{-1}\right)$ than during the intermediate $\left(0.17 \mathrm{UFL} \cdot \mathrm{d}^{-1}\right)$ and the wet seasons $\left(0.02 \mathrm{UFL} \cdot \mathrm{d}^{-1}\right)$.

The protein supply and total protein requirements were estimated to be 143 vs. $111 \mathrm{~g} \mathrm{PDI} \cdot \mathrm{d}^{-1}$ and $151 \mathrm{vs.} 144 \mathrm{~g}$ PDI $\cdot \mathrm{d}^{-1}$, respectively for the RM vs. RR ewes (Tab. V). Both traits differed within treatments and seasons with a significant $\mathrm{PM} \times \mathrm{S}$ interaction. The RM pastures allowed a higher $(P<0.01)$ protein supply than the
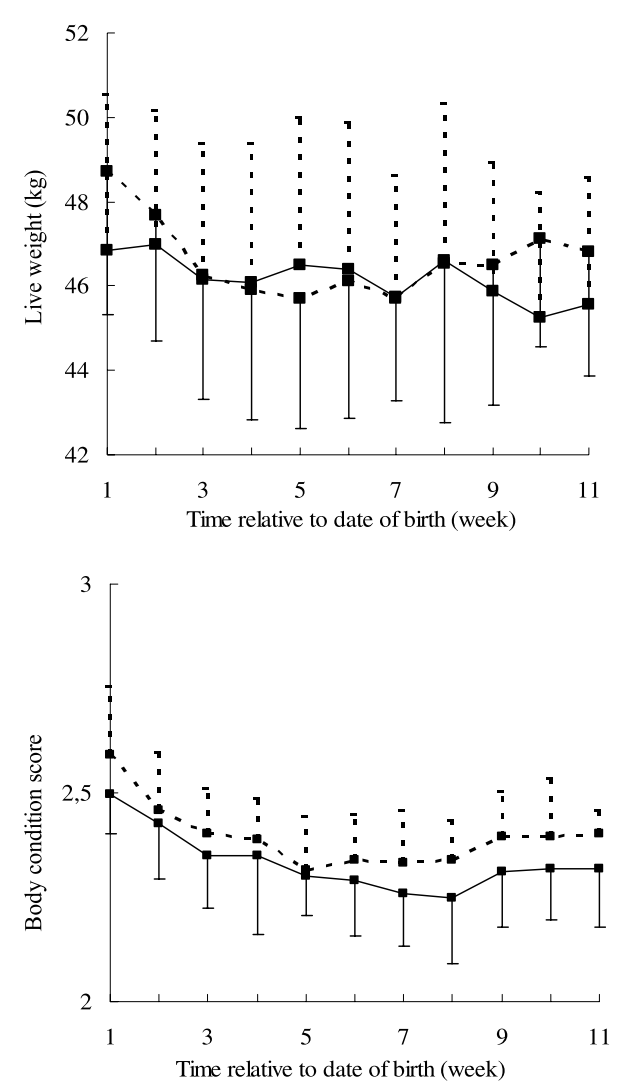

Figure 1. Average live weight $(\mathrm{kg})$ and body condition score (scale from 1 to 5) of Martinik ewes during lactation according to pasture management: Residuals Mown (RM, dotted lines) vs. Residuals Remained (RR, full lines). 
Table V. Energy and protein supplies and balances for suckling ewes reared in rotationally-grazed pasture according to pasture management and season.

\begin{tabular}{|c|c|c|c|c|c|c|c|c|c|c|}
\hline & \multicolumn{3}{|c|}{ Residuals mown } & \multicolumn{3}{|c|}{ Residuals remained } & \multirow[b]{2}{*}{ SEM } & \multicolumn{3}{|c|}{ Effect of } \\
\hline & DS & IS & WS & DS & IS & WS & & PM & $\mathrm{S}$ & $\mathrm{PM} \times \mathrm{S}$ \\
\hline Energy supply $\left(\mathrm{UFL} \cdot \mathrm{d}^{-1}\right)$ & 1.64 & 1.46 & 1.58 & 1.47 & 1.51 & 1.41 & 0.27 & NS & NS & $P<0.05$ \\
\hline Energy balance $\left(\mathrm{UFL} \cdot \mathrm{d}^{-1}\right)$ & 0.30 & 0.11 & 0.04 & 0.16 & 0.23 & 0.01 & 0.03 & $P<0.05$ & $P<0.01$ & $P<0.05$ \\
\hline Protein supply $\left(\mathrm{PDI} g \cdot \mathrm{d}^{-1}\right)$ & 146 & 119 & 166 & 115 & 110 & 108 & 18 & $P<0.01$ & $P<0.05$ & $P<0.05$ \\
\hline Protein balance (PDI $\left.g \cdot \mathrm{d}^{-1}\right)$ & 4 & -24 & -23 & -24 & -32 & -39 & -5 & $P<0.01$ & $P<0.01$ & NS \\
\hline
\end{tabular}

DS: dry season, IS: intermediate season, WS: wet season.

Effect of pasture management $(\mathrm{PM})$, season $(\mathrm{S})$ or interaction $\mathrm{PM} \times \mathrm{S}$ : level of significance; NS: non significant.

RR: $29 \%$ difference. The value was lower $(P<0.05)$ during the intermediate season $\left(114 \mathrm{~g}\right.$ PDI $\left.\cdot \mathrm{d}^{-1}\right)$ than during the dry $(130 \mathrm{~g}$ PDI. $\left.\mathrm{d}^{-1}\right)$ or the wet season $\left(137 \mathrm{~g} \mathrm{PDI} \cdot \mathrm{d}^{-1}\right)$. A protein deficiency $\left(-23 \mathrm{~g}\right.$ PDI. $\mathrm{d}^{-1}$ on average) has been calculated in almost all cases studied except for the RM ewes during the dry season. The protein balance significantly differed according to the PM and the season. The deficiency was lower $(P<0.01)$ for the RM than for the RR ewes: -15 vs. $-32 \mathrm{~g} \mathrm{PDI} \cdot \mathrm{d}^{-1}$ and lower $(P<0.01)$ during the dry season $\left(-10 \mathrm{~g}\right.$ PDI $\left.\cdot \mathrm{d}^{-1}\right)$ than during the intermediate $\left(-18 \mathrm{~g}\right.$ PDI $\left.\cdot \mathrm{d}^{-1}\right)$ and the wet season $\left(-31 \mathrm{~g}\right.$ PDI. $\left.\mathrm{d}^{-1}\right)$.

\section{DISCUSSION}

\subsection{Animal performances}

Digestibility and intake estimations for small ruminants at pasture are scarce in tropical areas. The intake of grazing suckling ewes in the present experiment ( 94 to $112 \mathrm{~g} \cdot \mathrm{kg}^{-0.75}$ DM) out-loaded the estimations reported by Avondo et al. [6] for dairy ewes (51 to $\left.68 \mathrm{~g} \cdot \mathrm{kg}^{-0.75} \mathrm{DM}\right)$ probably because they were reared under semi-extensive Mediterranean systems. Our values expressed as $\mathrm{g} \cdot \mathrm{d}^{-1} \mathrm{OM}(1.55-1.65)$ were quasi-similar to those reported by Penning et al. (1.64-1.81; [24]) when the amount of forage offered was similar: $42-63 \mathrm{~g} \cdot \mathrm{kg}^{-1} \cdot \mathrm{d}^{-1} \mathrm{OM}$ in the present study and $40-80 \mathrm{~g} \cdot \mathrm{kg}^{-1} \cdot \mathrm{d}^{-1} \mathrm{OM}$ in the experiment cited.
The values of milk yield and composition were similar or higher than what has been reported for other tropical hair sheep using a similar method of estimation [15, 21], although there are some limitations in using the oxytocin method for milk production assessment. This method is known to overestimate milk suckled by the young and to increase milk fat content value (because it allows the release of the milk contained in the udder acini), this has been observed with lactating ewes [13] and mares [14]. Moreover, the very frequent use of oxytocin might have a galactopoietic effect, but in our case it was used only once a week at the level of $5 \mathrm{UI}$ as recommended by Doney et al. [13]. Although the oxytocin method is not well adapted in order to characterise milk secretion ability per se, it has been used in our experiment with the objective to compare animal performances under different factors of variation and all the animals were subjected to the same milking procedure.

The high productive capacities of the ewes were also partly due to the drastic helminth control carried out in order to eliminate the tremendous negative impact of gastro-intestinal parasitism occurring in grazing systems [5].

\subsection{Effects of pasture management}

This experiment could not been replicated. Given that variations exist between 
paddocks, conclusions on forage characteristics must be made with caution. However, some indications can be underlined for comparisons between the different systems.

There were quantitative and qualitative forage differences between the two pasture systems: the biomass was higher in the RR system while it was the opposite for the CP content, with the RM system having a higher level. Probably this had resulted in quasi-similar feeding conditions and consequently animal performances in the two groups, since there was no significant difference in intake and milk production according to the pasture management.

Furthermore, the lack of PM difference may be due to the fact that the forage allowance and composition were not the limiting factors. Firstly, the biomass reached on average $2.5 \mathrm{t} \cdot \mathrm{ha}^{-1} \mathrm{DM}$ in the RM system (and 1.5 times more in the control system) thus ensuring sufficient forage on offer to the animals. Minson [22] explained for tropical forages that, where the yield of forage exceeds $2.0 \mathrm{t} \cdot \mathrm{ha}^{-1} \mathrm{DM}$ and grazing is unrestricted, ruminants have no difficulty satisfying their appetite. Moreover, it is well known in the case of small ruminants, that increasing the level of herbage availability increases their intake level [7, 24]. Penning et al. [24] experimented with herbage allowance ranging from 40 to $160 \mathrm{~g} \cdot \mathrm{kg}^{-1} \cdot \mathrm{d}^{-1} \mathrm{OM}$; the results showed that intake increased up to a herbage allowance which was 5 times the amount of herbage eaten by the ewes. In our case, the herbage allowance was not as high as those tested in the aforementionned study, since values ranged from 40 to $64 \mathrm{~g} \cdot \mathrm{kg}^{-1} \cdot \mathrm{d}^{-1} \mathrm{OM}$ in the RR and RM systems and probably did not allow the increase of the intake level. The dams could have compensated by the way of their selective grazing behaviour to ensure a high level of DM intake, as reported by Baumont et al. [7]. Although this has not been studied, this could have acted markedly in our case since this hardy genotype is known to be adapted to grazing conditions $[11,21]$.
On the contrary, the herbage composition was quite satisfactory in tropical conditions, thus ensuring adequate performance levels. As an example, the $\mathrm{CP}$ content and the OMD values reached on average $100 \mathrm{~g} \cdot \mathrm{kg}^{-1} \mathrm{DM}$ and 0.675 , respectively; and it is worth mentioning that this value is rarely reported for tropical forages [4, 22], except for early stages of maturity [3].

When an interaction between pasture management and season was observed, the estimations of production level of the animals were consistent with those of intake. The levels of DMI and the MP in the dry season were higher for RM than for RR ewes (12\% difference in DMI and 20\% difference in milk). During this season (fresh and dry), the bioclimatic conditions of the rearing of the animals were probably more favorable than during the hot and humid conditions. As a matter of fact, Leng [19] has shown that ruminants reared in tropical regions eat less under a hot and humid environment.

\subsection{Energy and protein supplies}

The energy values agreed with theoretical energy requirements of suckling grazing ewes, although there are some difficulties in assessing nutrient requirements in tropical conditions since the literature is very scarce. In studies led with suckling ewes reared indoors [2], the recommendation of total energy supply was 1.11 UFL per kg milk produced. In the present study at pasture, a level of 1.51 UFL resulted in a production of $1.2 \mathrm{~kg}$ of milk on average. No negative energy balance was observed; in the same way, the LW and BCS of the dams did not vary significantly through lactation, thus indicating that probably the feeding level was adequate in both systems.

However, a negative protein balance, $-23 \mathrm{~g} \cdot \mathrm{d}^{-1} \mathrm{PDI}$ on average, was calculated in almost all PM and season groups. In fact, the protein supplies represented $95 \%$ and $77 \%$ of the total protein requirements in the RM and the RR systems, respectively. Probably the animals were not subjected to 
a too severe restriction, since they could have exerted their selective foraging behaviour and could have eaten the more leafy part of the sward [7, 20]. As a matter of fact, taking into account the daily DM intake comparatively to the amount of forage on offer, the refusal rate was $16 \%$ and $46 \%$ in the RM and RR groups, respectively. However, it is assumed [19] that a high extent of urea recycling can compensate for feeding deficiency of ruminants in the tropics. Although the LW changes tended to be negative, and could partly reflect the protein deficiencies, the differences failed to reach significance and represented only a 3\% relative loss which is not very high especially for this hardy genotype.

Moreover, the animals without strongyle disorders could have been in good nutritional conditions even at pasture without supplements. As a matter of fact, it is known [9] that gastrointestinal nematodes reduce nutrient availability to the host by reducing voluntary intake, nutrient absorption and efficiency and by increasing endogenous protein loss.

Concerning the PDI/UFL ratio, our values which were 73 to $105 \mathrm{~g}$ PDI/UFL, ranged within the values reported in a previous study [2], for ewes reared indoors receiving balanced diets ( 88 to $96 \mathrm{~g}$ PDI/ UFL) and were only $18 \%$ less than the INRA recommendations for lactating ewes of $50 \mathrm{~kg} \mathrm{LW}$ [18].

However, with energy and/or protein restrictions that could appear on the long term of such intensified systems, it is important, as recommended by INRA [18] and Purroy and Jaime [25], to plan adequate feeding strategies fitted to body reserve recovery.

\section{CONCLUSION}

Removing post-grazing residues in intensive grazing systems with suckling ewes reared in tropical conditions, did not change the intake level or milk production of the dams comparatively to the control system. The pasture conditions in the two systems seem to be adequate and were not limiting factors since forage availability and chemical composition were at satisfactory levels in tropical conditions.

The elimination of post-grazing residues by mowing tested in this work was experimental. Its high cost makes it commercially impractical. We recommend developing new grazing systems which would allow the use of post-grazing residues with associated herbivores instead of mowing and eliminating the herbage refusals. Such a "leader-follower" system could increase total production from pastures where land and energy-dense feeds are limited.

High prophylactic inputs were used in this experiment in order to analyse the effect of pasture management, feeding level independently of parasitism. On commercial farms, a lower control of parasitism is achieved. Further studies are thus required to take into account the possible interaction between pasture management and parasitism.

\section{ACKNOWLEDGEMENTS}

We gratefully acknowledge R. Arquet, O. Coppry, T. Kandassamy, P. Mulciba, A. Nepos and $\mathrm{W}$. Troupe, for their support during the field work and the help of G. Saminadin, B. Calif and C. Baptistin for laboratory analyses. We also wish to thank C. Assoumaya and J. Sainton for their comments on the improvement of the manuscript. The authors are grateful to both reviewers and also to Dr M. Doreau, Editor-in-Chief, for the constructive criticism and comments done that have improved the manuscript. This study has been supported by the "Region Guadeloupe" and the "European Community" (FEOGA). The first author is grateful to CONACYT, ANUIES and Colegio de Postgraduados de Mexico.

\section{REFERENCES}

[1] AFNOR, Association Française de Normalisation (Ed.), Aliments des animaux. Dosage de l'azote en vue du calcul de la teneur en protéines brutes norme NF V18-100, Paris , $4^{\mathrm{e}}$ ed., 1988, pp. 87-100.

[2] Alexandre G., Archimède H., Chevaux E., Aumont G., Xandé A., Feeding supply of 
suckling Martinik ewes in intensive conditions: effects of supplement level and litter size, Anim. Res. 50 (2001) 213-221.

[3] Archimède H., Boval M., Alexandre G., Xandé A., Aumont G., Poncet, C., Effect of regrowth age on intake and digestion of Digitaria decumbens consumed by Black-belly sheep, Anim. Feed Sci. Technol. 87 (2000) 153-162.

[4] Aumont G., Caudron I., Saminadin G., Xandé A., Sources of variation in nutritive values of tropical forages from the Caribbean, Anim. Feed Sci. Technol. 51 (1995) 1-13.

[5] Aumont G., Pouillot R., Simon R., Hostache G., Barré N., Varo H., Parasitisme digestif des petits ruminants dans les Antilles françaises, INRA Prod. Anim. 10 (1997) 79-90.

[6] Avondo M., Bordonaro S., Marletta D., Guastella A.M., D'Urso G., A simple model to predict the herbage intake of grazing dairy ewes in semi-extensive mediterranean systems, Livest. Prod. Sci. 73 (2002) 275-283.

[7] Baumont R., Prache S., Meuret M., MorandFehr P., How forage characteristics influence behaviour and intake in small ruminants: $\mathrm{A}$ review, Cah. Options Méditerr. 52 (2000) 1125.

[8] Boval M., Archimède H., Fleury J., Xandé A., The ability of faecal nitrogen to predict digestibility for goats and sheep fed with tropical herbage, J. Agric. Sci. (Camb.) 140 (2003) 1-8.

[9] Coop R.L., Kyriazakis I., Nutrition-parasite interaction, Vet. Parasitol. 84 (1999) 187-204.

[10] Corsi M., Martha G.B., Do Nascimento D. Jr., Balsalobre M.A.A., Impact of grazing management on productivity of tropical grasslands, in: Proceedings of the XIX International Grazing Congress, Sao Paulo, Brasil, 11-21 February, 2001, pp. 801-811.

[11] Devendra C., Mc Leroy G.B., Goat and sheep production in the Tropics. Intermediate Tropical Agricultural Series, Longman, London and New York, 1982.

[12] Daget P., Poissonet J., Méthode d'analyse de la végétation des pâturages. Critères d'application, Ann. Agron. 22 (1971) 5-41.

[13] Doney J.M., Peart J.N., Smith W.F., Louda F., A consideration of the techniques for estimation of milk yield by suckled sheep and a comparison of estimates obtained by two methods in relation to the effect of breed, level of production and stage of lactation, J. Agric. Sci. (Camb.) 92 (1979) 123-132.

[14] Doreau M., Boulot S., Martin-Rosset W., Dubroeucq H., Milking lactating mares using oxytocin: milk volume and composition, Reprod. Nutr. Dev. 26 (1986) 1-11.
[15] Godfrey R.W., Gray M.L., Collins J.R., Lamb growth and milk production of hair and wool sheep in a semi-arid tropical environment, Small Ruminant Res. 24 (1997) 77-83.

[16] Hughes F.P., Mathews P.N.P., Mathew C., The effects of post-grazing sward conditions on herbage accumulation in winter and spring, in: Proceedings of the XIX International Grazing Congress, Sao Paulo, Brasil, 11-21 February, 2001, pp. 824-825.

[17] Humphreys L.R., Tropical pasture utilization, 1st ed., Cambridge University, Great Britain, 1991

[18] Institut National de la Recherche Agronomique (INRA), in: Jarrige R. (Ed.), Ruminant nutrition. Recommended allowances and feed tables, John Libbey Eurotext, London-Paris, 1989.

[19] Leng R.A., Factors affecting the utilization of "poor-quality" forages by ruminants particularly under tropical conditions, Nutr. Res. Rev. 3 (1990) 277-303.

[20] L'Huillier P.J., Poppi D.P., Fraser T.J., Influence of structure and composition of ryegrass and prairie grass-white clover swards on the grazed horizon and diet harvested by sheep, Grass Forage Sci. 41 (1986) 259-267.

[21] Mahieu M., Aumont G., Alexandre G., Élevage intensif des ovins tropicaux à la Martinique, INRA Prod. Anim. 10 (1997) 21-32.

[22] Minson D.J., Forage in Ruminant Nutrition, Academic Press Inc., New York, 1990.

[23] Ortega-Jimenez E., Alexandre G., Arquet R., Coppry O., Mahieu M., Xandé A., Consequences of Post-grazing residues control and lambing season on the body traits, reproductive performance and offspring's growth of suckling goats and ewes reared at pasture in Guadeloupe (FWI), Asian Aust. J. Anim. Sci. 16 (2003) 1108-1117.

[24] Penning P.D., Hooper G.E., Treacher T.T., The effect of herbage on intake and performance of ewes suckling twin lambs, Grass Forage Sci. 41 (1986) 199-208.

[25] Purroy A., Jaime C., The response of lactating and dry ewes to energy intake and protein source in the diet, Small Ruminant Res. 17 (1995) 17-24.

[26] Russel A.J.F., Doney J.M., Gunn R.G., Subjective assessment of body fat in live sheep, J. Agric. Sci. (Camb.) 72 (1969) 451-454.

[27] SAS, User's guide, Statistics, SAS Inst. Inc., Cary, NC, 1988.

[28] Van Soest P.J., Robertson J.B., Lewis B.A., Methods for dietary fiber, neutral detergent fiber, and nonstarch polysaccharides in relation to animal nutrition, J. Dairy Sci. 74 (1991) 3583-3597. 